\title{
Understanding the mechanisms of the relationship between shared values and service delivery performance of frontline employees
}

\begin{abstract}
Service firms strive to encourage their frontline employees (FLEs) to develop attitudes and behaviors that support excellent service delivery. Anchored in the conservation of resources (COR) theory, this study aims to understand the mechanisms through which shared values influence FLEs' service delivery performance. The study contributes to the HRM literature by developing and testing a conceptual framework among FLEs in the British hospitality industry. Findings reveal that shared values as a key workplace resource enhances the service delivery performance of FLEs through the following key intervening mechanisms: perceived organizational support, emotional exhaustion, job satisfaction, and affective organizational commitment. Findings further demonstrate a direct relationship between shared values and emotional exhaustion and an indirect relationship between emotional exhaustion and service delivery performance via affective organizational commitment and job satisfaction. Managerial implications and suggestions for future research are presented.
\end{abstract}

Keywords: shared values; conservation of resources theory; emotional exhaustion; service delivery performance; perceived organizational support; affective organizational commitment; job satisfaction; FLEs. 


\section{Understanding the mechanisms of the relationship between shared values and service delivery performance of frontline employees}

\section{Introduction}

Facing increasingly competitive markets, service firms strive to encourage their frontline employees (FLEs) to develop attitudes that support excellent service delivery as a way of differentiating themselves from other firms and to achieve competitive advantage (He, Wenli, \& Lai, 2011; Hur, Moon, \& Jun, 2013). Service delivery performance as an FLE behavior drives customer evaluations of the company and, ultimately, company performance (see Hur et al., 2013). Considering that excellent service delivery as an FLE behavior is crucial for any organization's success (Chen, Tsou, \& Huang, 2009), there is the need to further examine the mechanisms underlying the relationship of shared values between employees and the company, and key FLE behavioral outcomes (Edwards \& Cable, 2009; Maden \& Kabasakal, 2014). Shared values capture the congruence of values between the employee and the company (Hartline, Maxham III, \& McKee, 2000). Values are generally viewed as fundamental, relatively enduring, and guiding employee behavior (Cable \& Judge, 1996), ultimately impacting service delivery performance. Unpacking the mechanisms of this relationship is thus crucial for both employees and organizations.

Generally speaking, when employees' values are aligned with those of the organization, employees will be more fulfilled in their jobs. As a consequence, organizations are expected to show lower turnover costs, increase employee retention (Edwards \& Cable, 2009; Presbitero, Roxas, \& Chadee, 2016), and enhance task performance (see Verquer, Beehr, \& Wagner, 2003). Despite the literature acknowledging the importance of shared values in driving positive outcomes (e.g., Edwards \& Cable, 2009; Presbitero et al., 2016), there is a paucity of empirical research on the mechanisms underlying the relationship between shared values and favorable outcomes (Edwards \& Cable, 2009). Accordingly, this study develops a conceptual framework aimed at understanding the mechanisms 
through which shared values influence FLEs' service delivery performance. Anchored in the conservation of resources (COR) theory (Hobfoll, 1988, 1989), this relationship is examined via the intervening mechanisms of perceived organizational support (POS), emotional exhaustion, and attitudes (affective organizational commitment and job satisfaction), in a single parsimonious framework.

The research contribution to the human resource management literature is threefold. First, the literature calls for the understanding of the relevance of shared values between employees and organizations (Watrous, Huffman, \& Pritchard, 2006). While the importance of shared values is acknowledged in marketing (see Hartline et al., 2000; Maxham III \& Netemeyer, 2003), organizational behavior, and psychology works (Cable \& DeRue, 2002; Howell, Kirk-Brown, \& Cooper, 2012; Watrous et al., 2006), and a considerable amount of research examines the relationship between value congruence and outcomes, only a few studies have focused on why this relationship exists (Edwards \& Cable, 2009). Empirical findings examining the effects of shared values on employee behavioral outcomes are limited and equivocal (Edwards \& Cable, 2009; Maden \& Kabasakal, 2014; Meglino \& Ravlin, 1998). Hence research should seek additional explanations for this relationship (Edwards \& Cable, 2009). This study provides insights into the relationship between value congruence and behavioral outcomes, utilizing COR theory to explore the mechanisms through which shared values may influence service delivery performance of FLEs.

Second, further research is needed into exploring key workplace resources (e.g., shared values) that may contribute to the prevention of burnout (see Demerouti \& Bakker, 2011; Hobfoll, 2011). Emotional exhaustion is a relevant dimension of burnout, in particular for FLEs (Singh, Goolsby, \& Rhoads, 1994). While it is widely acknowledged that FLEs often experience emotional exhaustion due to the demanding and stressful nature of their role (Karatepe, 2013, 2015), firms ought to mitigate emotional exhaustion's negative effects on performance by understanding its antecedents. This study investigates the neglected relationship between shared values and emotional exhaustion of FLEs. 
Third, more research is required to fully understand how emotional exhaustion influences FLE performance (see Witt, Andrews, \& Carlson, 2004), regarding the service related aspects of FLE job performance. While the impact of emotional exhaustion on job performance has been previously addressed (e.g. Halbesleben \& Bowler, 2007; Witt et al., 2004; Wright \& Cropanzano, 1998), the nature of this effect varies widely (Tourigny, Baba, Han, \& Wang, 2013). Emotional exhaustion can have a different effect on distinct aspects of job performance, for example, productivity or service quality (Witt et al., 2004). In order to contribute toward a better understanding of contentions in the literature that emotional exhaustion may not directly impact some service-related aspects of FLE job performance (see Witt et al., 2004), the study examines the connection between emotional exhaustion and service delivery performance.

\section{Theoretical background and research hypotheses}

\section{Conservation of resources theory}

COR theory (Hobfoll, 1988, 1989), as a general motivation theory, explains why employees are motivated to gain, protect, and enhance personally valued resources (Wheeler et al., 2012). Resources are defined as 'those objects, personal characteristics, conditions, or energies that are valued by the individual or that serve as a means for attainment of these objects, personal characteristics, conditions or energies' (Hobfoll, 1989, p. 516). These resources affect employee job performance (Wright \& Cropanzano, 1998; Wright \& Hobfoll, 2004), as they provide emotional resilience and give employees a sense of control over their environment (Hobfoll, 1989; Hobfoll, Johnson, Ennis, \& Jackson, 2003).

This study builds on COR theory (Hobfoll, 1988, 1989), by investigating the role of shared values as a key workplace resource (Mitchell et al., 2001; Wheeler et al., 2012). Since shared values provide 'the best measure of person-organization fit in employment settings' (Morgan \& Hunt, 1994, p. 25), shared values are a highly valued and sought-after resource as they help people define who they are. As such, employees' 'fit with the values of their employers' also influences their performance 
(Wheeler et al., 2012, p. 245). Hence, shared values as a key precursor of employee attitude and behavior at work (besides rewards and punishments) (Morgan \& Hunt, 1994) greatly facilitate the implementation of a firm's strategy and enhance its overall performance (Hartline et al., 2000).

Conservation of Resources theory suggests that resources are linked to other resources and resources facilitate the development and use of other resources (see Hobfoll, 2011). The implications in terms of shared values is that employees with shared values are able to mobilize their resources better and hence are likely to develop more resources at work than those employees who do not share values with their organization (Bakker \& Demerouti, 2007). In other words, employees with shared values are likely to perceive more organizational support (Cable \& DeRue, 2002; Kurtessis et al., 2015; Watrous et al., 2006) and less emotional exhaustion. COR theory advocates that emotional exhaustion negatively influences employee job attitudes, which in turn, affect service delivery performance.

\section{Research hypotheses}

Drawing on COR theory and the HRM literature, this study proposes a conceptual framework (see Figure 1), with the underlying rationale that shared values enhance service delivery performance of FLEs via key mediating mechanisms: POS, emotional exhaustion, affective organizational commitment and job satisfaction.

\section{[INSERT FIGURE 1 ABOUT HERE]}

While shared values are a key element of an organization's culture (Hartline et al., 2000; Meglino \& Ravlin, 1998), POS represents the extent to which employees believe that the organization values their contributions and cares about their welfare (Eisenberger, Huntington, Hutchison, \& Sowa, 1986; Hayton, Carnabuci, \& Eisenberger, 2012; Rhoades \& Eisenberger, 2002). Shared values and POS are theoretically related as employees ascribe dispositional traits and values to their organization that match 
their personal values (Cable \& DeRue, 2002). Employees who share values with their organization are 'more likely to attribute positive motives to the organization's behaviors and actions toward them' (Cable \& DeRue, 2002, p. 876) and thus, 'when shared values are high, there are a number of positive consequences such as...greater perceived organizational support' (Watrous et al., 2006, p. 109). According to the attraction-selection-attrition framework (Schneider, Goldstein, \& Smith, 1995), individuals are attracted to, prefer to be a part of, and stay with those organizations whose general values they share. This is because 'individuals are generally attracted to and feel most comfortable with people who are "like them" or "see things" the way they do' (Locke, 1976, p. 1327).

Accordingly, when employees share the values of their organization, they are likely to view their working environment more positively (Schneider et al., 1995) and thus are able to mobilize their resources better. As such, they are likely to perceive more resources at work than those who do not share values with their organization (Bakker \& Demerouti, 2007). Moreover, FLEs who share the values of their organization have a higher perceived fit with the organization (Cable \& Judge, 1996), which makes them feel part of the 'in-group' and feel supported by the organization (Presbitero et al., 2016). Hence employees with shared values are likely to perceive more organizational support (Cable \& DeRue, 2002; Kurtessis et al., 2017; Watrous et al., 2006). Conversely, employees who do not share the values of their organization will be less trusting of the organization's motives and consequently will perceive the organization to be less supportive (Cable \& DeRue, 2002). Hence we propose:

H1. Shared values between employees and the firm are positively related to employee POS.

Emotional exhaustion reflects a lack of energy and a sense of being drained (Babakus, Cravens, Johnston, \& Moncrief, 1999; Singh at al., 1994). Emotional exhaustion may be described as 'a feeling of depleted energy resulting from excessive psychological and emotional demands on people working in helping professions' (Mulki, Jaramillo, \& Locander, 2007, p. 562). Conservation of resources theory 
suggests that when employees are required to perform behaviors that threaten their basic values, they experience emotional exhaustion (Hobfoll, 2011). This finding is corroborated in the services literature, which demonstrates that FLEs lacking shared values are likely to become quickly frustrated when dealing with customers and experience more emotional exhaustion (Maxham III \& Netemeyer, 2003). Since the way employees perceive and evaluate their work environment is influenced by their work values, employees who share similar values are likely to perceive their work environment similarly (Young \& Parker, 1999). As such, value congruence reflects a lower employee-organization clash (Kristof, 1996). This is because when values are socially endorsed by the organization and shared by FLEs, it creates 'an organizational culture in which employees are similar in their behaviors and orientations toward the firm and customers' (Maxham III \& Netemeyer, 2003, p. 49).

As value congruence facilitates open exchange of information and increases predictability among organizational members (Edwards \& Cable, 2009), employees with higher shared values may experience less anxiety and dissonance in their work environment, enabling them to perform their tasks smoothly (Maden \& Kabasakal, 2014). Accordingly, frontline employees who share organizational values are likely to perceive relatively lower job demands and complain less about their workload, which creates a positive work climate that reduces the likelihood of developing emotional exhaustion (Bakker \& Schaufeli, 2000). Shared values may therefore act as a critical resource as they create a context in which emotional exhaustion of FLEs is less likely to occur. Given that FLEs are the link between the company and its customers (Karatepe, 2013), it is important that their values are aligned with organizational values. If values are misaligned, FLEs are likely to suffer higher levels of emotional exhaustion. It is proposed that:

$H 2$. The level of shared values between employees and the firm is negatively related to employee emotional exhaustion. 
Frontline employees who perceive organizational support to be high usually experience fewer strain symptoms (Rhoades \& Eisenberger, 2002) and lower burnout rates (Cropanzano, John, Grandey, $\&$ Toth, 1997). The more supportive the environment in which employees work, the lower their stress level intensity tends to be (Cropanzano et al., 1997). Given that earlier research has found that unfavorable treatment by a supervisor (i.e. unpleasant supervisor contact) has a positive impact on emotional exhaustion (Leiter \& Maslach, 1988), and that this treatment is likely to be perceived as representing low organizational support (Rhoades \& Eisenberger, 2002), increased emotional exhaustion levels are expected. Accordingly, and in line with recent research in the hospitality industry (Karatepe, 2015; Lages \& Piercy, 2012), it is proposed that:

H3. Employee POS is negatively related to employee emotional exhaustion.

Affective organizational commitment is the strength of an employee's identification with and contribution to a particular organization (Mowday, Steers, \& Porter, 1979; Porter, Steers, Mowday, \& Boulian, 1974). High burnout and emotional exhaustion levels lead to diminished affective organizational commitment (Alarcon, 2011; Hobfoll, 1989; Tourigny et al., 2013). That is, as burnout increases, employees will present lower levels of identification and willingness to contribute to the organization. This idea is reflected in COR theory, which argues that 'exhausted individuals will attempt to reduce further loss of resources, and when unsuccessful, they will engage in withdrawal coping mechanisms to reduce the psychological costs of exhaustion (Deery, Iverson, \& Walsh, 2002; Schaufeli \& Bakker, 2004)' (Thanacoody, Newman, \& Fuchs, 2014, p. 1844). A possible route employees may pursue to diminish the costs of exhaustion is to reduce their commitment to the organisation. This negative impact of emotional exhaustion on affective organizational commitment may be further explained by the fact that emotional exhaustion is costly and regarded as unjustified for the individual. This suggests that emotional exhaustion hinders the proliferation of high quality working relationships, 
resulting in lower affective organizational commitment (Cropanzano, Rupp, \& Byrne, 2003). That is, emotionally exhausted employees tend to be less eager and compliant with the goals of the organization and less willing to achieve those goals (Leiter \& Maslach, 1988). This reflects a lower identification with and contribution to the organization (Mowday et al., 1979; Porter et al., 1974). Hence the following relationship is hypothesized:

H4. Employee emotional exhaustion is negatively related to employee affective organizational commitment.

Job satisfaction may be defined as an individual's psychological well-being on the job (Singh et al., 1994). As per COR theory, emotional exhaustion results from an assessment of job demands in relation to an employee's resources, and this evaluation process will affect an employee's well-being on the job, and in particular their job satisfaction (Martinussen, Richardsen, \& Burke, 2007). Emotional exhaustion has been found to be negatively related to job satisfaction in frontline bank employees (Karatepe, 2006) as well as professors (Mahoney, Buboltz, Buckner, \& Doverspike, 2011). Hence it is proposed that:

H5. Employee emotional exhaustion is negatively related to employee job satisfaction.

When employees perceive high levels of organizational support, they are expected to offer affiliation and loyalty in return (Eisenberger, Fasolo, \& Davis-LaMastro, 1990). Affective organizational commitment has consistently been found to be positively associated with POS (Kurtessis et al., 2015; Rhoades \& Eisenberger, 2002; Riggle, Edmondson, \& Hansen, 2009; Vandenberghe et al., 2007), and more specifically to be an outcome of POS (Panaccio \& Vandenberghe, 2009; Rhoades \& Eisenberger, 2002). This result holds across various contexts, including fast-food outlets and restaurants 
(Lages \& Piercy, 2012), hotels (see He et al., 2011), and retailing (Rhoades, Eisenberger, \& Armeli, 2001), among others. If an employee perceives high levels of organizational support, the employee is expected to offer affiliation and loyalty in return (Eisenberger, Fasolo, \& Davis-LaMastro, 1990). An underlying premise for this relationship is Gouldner's (1960) norm of reciprocity, whereby the employee is encouraged to respond favorably to an organization's concern for his/her well-being, which creates an emotional attachment to the firm (Rhoades et al., 2001). It is proposed that:

H6. Employee POS is positively related to employee affective organizational commitment.

Perceived organizational support and job satisfaction are positively connected (Eisenberger, Cummings, Armeli, \& Lynch, 1997; Riggle et al., 2009). It is expected that when employees believe that the organization values their contribution, they will be more satisfied in their jobs. Perceived organizational support impacts positively on job satisfaction through three mechanisms: first, by satisfying various socio-emotional needs (Armeli, Eisenberger, Fasolo, \& Lynch, 1998); second, by enhancing performance-reward expectations; and, third, by showing availability of help when required (Rhoades \& Eisenberger, 2002). Additionally, employees with high POS usually consider their job more pleasant and are happier at work (Rhoades \& Eisenberger, 2002), showing higher levels of psychological well-being in their jobs. Hence it is proposed that:

H7. Employee POS is positively related to employee job satisfaction.

Job satisfaction is strongly and positively related to organizational commitment (Lages \& Piercy, 2012; Meyer, Stanley, Herscovitch, \& Topolnytsky, 2002) with most research considering job satisfaction an antecedent of organizational commitment (Gunlu, Aksarayli, \& Perçin, 2010). Job satisfaction captures the way the employee responds to their specific job issues (Gunlu et al., 2010) and 
is 'transitory in nature' (Porter et al., 1974, p. 698). That is, job satisfaction may vary over time being a quicker and less stable response. Organizational commitment entails a global and more consistent response to the organization over time (Gunlu et al., 2010). When employees feel dissatisfied with their job, they will distance themselves from the organization, ultimately developing lower organizational commitment (Mahoney et al., 2011). Conversely, it is expected that an employee who is consistently satisfied with their job over time will tend to develop a stronger identification with, and potentially attain a higher affective commitment toward the organization. It is proposed that:

H8. Employee job satisfaction is positively related to employee affective organizational commitment.

Service delivery performance relates to FLEs providing service in a 'conscientious, responsive, attentive, and courteous manner' (Bettencourt \& Brown, 2003, p. 395). Conservation of resources theory explains the negative impact of emotional exhaustion on service delivery performance. Since FLEs are required to meet the demands of multiple role partners (Malhotra \& Ackfeldt, 2016), they experience emotional exhaustion as they feel that their resources may not be sufficient to meet current work demands (Halbesleben \& Bowler, 2007). In particular, when employees get emotionally exhausted their energy is reduced (Singh et al., 1994) and they are left with fewer resources to meet further performance requirements (Karatepe, Yorganci, \& Haktanir, 2009). Under such circumstances, it is expected that employees look for ways by which they can safeguard or replenish their depleting resources (Halbesleben \& Bowler, 2007; Hobfoll, 2001). Withholding their effort and performance levels is found to be one of the common coping strategies in such circumstances (e.g., Cropanzano et al., 2003; Halbesleben \& Bowler, 2007; Tourigny et al., 2013). It is proposed that:

H9. Employee emotional exhaustion is negatively related to employee service delivery performance. 
Studies have found that affective organizational commitment has a strong positive impact on FLE service recovery performance in, for example, the financial services sector (Babakus, Yavas, Karatepe, \& Avci, 2003; Boshoff \& Allen, 2000). The underlying reason appears to be that individuals who are affectively committed to their organization are willing to dedicate more time and effort to their work and, consequently, perform better (Boshoff \& Allen, 2000; Furtmueller, Van Dick, \& Wilderom, 2011). Hence it is hypothesized that:

H10. Employee affective organizational commitment is positively related to employee service delivery performance.

Employee job satisfaction is related to service performance (Babakus et al., 2003; Bettencourt \& Brown, 2003; Yoon, Beatty, \& Suh, 2001). The rationale is that, at first, individuals are conscious of their own feelings; then, individuals relate those feelings to particular job features; and, finally, they act in accordance with these feelings (e.g., if the individual is satisfied with the job, they will do their best to perform well) (Bagozzi, 1980). Additionally, 'satisfied employees are more likely to engage in behaviors that assist customers' and, as job satisfaction is naturally visible during service delivery, it contributes to higher perceptions of employee service performance (Yoon et al., 2001, p. 505). This logic leads us to propose that:

H11. Employee job satisfaction is positively related to employee service delivery performance.

\section{Bridging shared values and service delivery performance}

Research on shared values has attempted to explain why value congruence affects positive outcomes, yet a limited number of explanations has been tested empirically (Edwards \& Cable, 2009). Our research 
seeks additional explanations for this relationship. Based on the above mentioned hypotheses, the study considers four constructs as key explanations of the process by which shared values relate to service delivery performance. These are POS, which is an organizational driven factor, and emotional exhaustion, job satisfaction, and affective organizational commitment as individual drivers (cf. Lages \& Piercy, 2012). Hence this study tests these mechanisms as intervening variables on the shared valuespositive outcomes relationship.

\section{Method}

\section{Sample and data collection}

The research design entailed a survey. Data were collected from frontline catering employees in one of the major motorway service-area operators that specializes in fast-food outlets and restaurants in the UK. Frontline catering employees were selected as respondents for three reasons. First, fast-food outlets and restaurants are high-contact retail service businesses (see Bitner, Booms, \& Tetreault, 1990), in which a substantial amount of interaction between the customer and the provider of the service occurs (Berry, 1980). Second, FLEs are particularly exposed to emotional exhaustion as a result of their boundary role in the organization (see Singh et al., 1994). Third, as they spend a considerable amount of time in contact with the customer (Hartline et al., 2000), they are responsible for applying the marketing concept in service companies (see Donavan, Brown, \& Mowen, 2004) and are thus well placed to deliver excellent service.

All catering employees in the company received an envelope that contained a cover letter and a questionnaire. To encourage honesty, employees were given written assurance that their responses would remain confidential. The catering employees completed their questionnaire during working hours and returned it in a sealed, prepaid envelope addressed to the researchers. Of the 2,324 survey questionnaires distributed to employees, 740 were valid, resulting in a final response rate of $31.8 \%$. The majority of respondents were female (61.9\%), younger than 25 years old (52.5\%), and worked on a full- 
time basis $(60.5 \%)$. After the inclusion of control variables, namely age, gender, and tenure, and based on listwise deletion, the sample was reduced to 707 respondents who were subsequently used in the analysis.

\section{Measures}

The questionnaire included multi-item measures drawn from the extant literature on shared values, POS, emotional exhaustion, affective organizational commitment, job satisfaction, and service delivery performance. Shared values were measured using a scale by Hartline et al. (2000) based on Enz (1986) and Wasmer and Bruner's (1991) work, which assesses the degree to which FLEs share the values of their organization with regards to professionalism, ethics, creativity, industry leadership, superior quality and service, and employee morale and satisfaction. Perceived organizational support was measured using the short form of the survey of POS (Eisenberger et al., 1986). This scale assesses the extent to which employees believe that the organization values their contributions and cares about their welfare. Emotional exhaustion was measured using Babakus et al.'s (1999) emotional exhaustion subscale of the Maslach burnout inventory (Maslach \& Jackson, 1986), which assesses employees' 'feelings of being emotionally overextended and drained by one's contact with other people' (Leiter \& Maslach, 1988, p. 297). Affective organizational commitment was measured using Hartline et al.'s (2000) short version of the scale developed by Mowday et al. (1979). This scale assesses the degree to which employees feel affectively committed to the employing organization. Job satisfaction reflects an individual's psychological well-being on the job (Singh et al., 1994). It was measured using Judge and Colquitt's (2004) short version of the scale developed by Brayfield and Rothe (1951). Finally, service delivery performance was measured using Bettencourt and Brown's (2003) scale, which assesses the extent to which the FLE serves 'customers in a conscientious, responsive, attentive, and courteous manner' (p. 395). 


\section{Assessment of common method bias}

To control for common method bias, this study followed six procedural remedies suggested by Podsakoff, MacKenzie, Podsakoff, and Lee (2003). First, in terms of item characteristics, the questionnaire items were written as clearly and concisely as possible, given the constraints of adapting them from extant literature. This procedure allows for the reduction of the ambiguity of the items (Podsakoff, MacKenzie, \& Podsakoff, 2012). Second, the scale formats ('strongly disagree' to 'strongly agree'; 'not at all characteristic of me' to 'extremely characteristic of me'; 'definitely false' to 'definitely true'), anchors and values ( 1 to 5 vs. 1 to 7 ) differed across constructs, which allows for the removal of common scales properties (Podsakoff et al., 2012). Third, and as suggested by Podsakoff et al. (2003), the medium used to collect data was paper-and-pencil questionnaires rather than face-to-face interviews. Fourth, to control for social desirability and to obtain responses that reflect employees' true feelings, respondents were guaranteed confidentiality. Fifth, in the cover letter, respondents were asked to answer the questionnaire honestly and they were informed that there were no 'right' or 'wrong' answers. Sixth, to counter the effect that implicit theories might have had on respondents' answers, they were not informed about the conceptual framework of the study.

In addition to the procedural remedies, statistical remedies were employed to address common method bias issues. First, we conducted Harman's single-factor test; all items were loaded into a single exploratory factor analysis with a non-rotated solution (see Podsakoff \& Organ, 1986). The first factor that emerged from the data does not explain more than $50 \%$ of the data variance - it accounts for $36.6 \%$ of the variance (Podsakoff et al., 2003), and thus common method bias is not an issue in this study. Second, this study used the correlation-based marker variable technique (Lindell \& Whitney, 2001), which has been widely employed recently (Podsakoff et al., 2012; Williams, Hartman, \& Cavazotte, 2010). Accordingly, a marker variable, which is theoretically unrelated with the variables of interest, was identified, namely 'contract' (whether employees work on a full-time or part-time basis). The correlation of this 'contract' variable with the variables of interest is non-significant. In particular, the 
correlation of the marker variable with our ultimate dependent variable, service delivery performance, is -0.015 (non-significant). Next, the smallest positive correlation between the marker variable and the variables of interest, in this case with POS (0.022), was used as an estimate of common method variance (CMV). Subsequently, this estimate was used in the partial-correlation adjustment for CMV between the ultimate dependent variable and each predictor variable. Results reveal that the original correlations that were significant remained significant after controlling for CMV, which 'suggests that the results cannot be accounted for by CMV' (Lindell \& Whitney, 2001, p. 118). Thus common method bias is not a major problem in this study.

\section{Data analysis}

\section{Measurement validation}

Results reveal high internal reliability for all scales (Cronbach, 1951). Cronbach's alpha values were at acceptable levels for all the measures (Table 1). To assess the validity of the measures, the items were subjected to a confirmatory factor analysis (CFA) using the maximum likelihood (ML) estimation procedures in LISREL 9.2 (Jöreskog \& Sörbom, 2015). Despite the chi-square significance $\left(\chi^{2}=819.56\right.$, $d f=344, p$-value $<0.001)$, the final measurement model with 26 items, based on the sample of 707 respondents, fits the data well $(\mathrm{NFI}=0.95, \mathrm{NNFI}=0.96, \mathrm{CFI}=0.97, \mathrm{IFI}=0.97, \mathrm{RMSEA}=0.044$; see Table 2).

\section{[INSERT TABLES 1 AND 2 ABOUT HERE]}

To assess convergent validity, the magnitude and statistical significance ( $z$-values) of the factorloading estimates are examined. Convergent validity is evidenced by the large and significant standardized loadings of each item on its intended construct (Table 2). Regarding composite reliability, a value of 0.70 or higher indicates good reliability (Hair, Black, Anderson, Babin, \& Tatham, 2006). A 
value for average variance extracted (AVE) of 0.50 or higher is reported for each individual construct, suggesting adequate convergence (Fornell \& Larcker, 1981). Evidence of discriminant validity is found for all six constructs (Table 1). The AVE for each construct is superior to the squared correlation coefficient between that construct and all other constructs (Fornell \& Larcker, 1981). Table 2 presents the results of the overall measurement model, including standardized loadings, $z$-values, and model fit.

\section{Testing of hypotheses}

A structural equation model (SEM) is employed to test the 11 hypotheses. Although the $\chi^{2}$ is significant $\left(\chi^{2}=823.65, d f=348, p\right.$-value $\left.<0.001\right)$, all the indices suggest a good fit of the final model to the data $(\mathrm{NFI}=0.95, \mathrm{NNFI}=0.96, \mathrm{CFI}=0.97, \mathrm{IFI}=0.97, \mathrm{RMSEA}=0.044 ;$ see Table 3$)$.

\section{[INSERT TABLE 3 ABOUT HERE]}

An examination of the individual paths demonstrates that 9 out of the 11 hypotheses are confirmed (Table 3). With regard to resources, $H 1$ is confirmed, as SV positively impacts POS $(0.30, p<0.01)$. Similarly, with regard to the determinants of emotional exhaustion, $H 2$ and $H 3$ are supported. Both shared values and POS negatively influence emotional exhaustion $(-0.12, p<0.01 ;-0.53, p<0.01$; respectively). In terms of the determinants of job attitudes, $H 4, H 5, H 6, H 7$, and $H 8$ are supported. With regard to affective organizational commitment drivers, findings reveal that emotional exhaustion has a negative effect on affective organizational commitment $(-0.08, p<0.05)$, while POS and job satisfaction positively influence affective organizational commitment $(0.48, p<0.01 ; 0.40, p<0.01$; respectively). With regard to the antecedents of job satisfaction, POS positively influences job satisfaction $(0.53, p<0.01)$ while emotional exhaustion has a negative effect on job satisfaction $(-0.33$, $p<0.01)$.

Finally, with regard to service delivery performance, results reveal that emotional exhaustion had no impact on service delivery performance $(-0.08, n s)$. While affective organizational commitment 
impacted service delivery performance positively $(0.26, p<0.01)$, job satisfaction had no impact on service delivery performance $(0.01, n s)$. Thus while support is found for $H 10$, there is no support for H9 and H11. Figure 2 summarizes the results.

\section{[INSERT FIGURE 2 ABOUT HERE]}

In order to further explore the non-supported hypotheses ( $H 9$ and $H 11)$, we estimated the indirect and total effects (Bollen, 1989). The indirect relationships between emotional exhaustion and service delivery performance, and between job satisfaction and service delivery performance, are statistically significant (Table 3). More specifically, the indirect effect of emotional exhaustion on service delivery performance (through affective organizational commitment and job satisfaction) is negative and statistically significant $(-0.06, p<0.01)$ contributing in this way to the total effect of emotional exhaustion on service delivery performance being significant $(-0.15, p<0.01)$. Moreover, the indirect effect of job satisfaction on service delivery performance through affective organizational commitment is positive and statistically significant $(0.12, p<0.01)$. This indirect effect helps make the total effect of job satisfaction on service delivery performance significant $(0.14, p<0.10)$.

\section{Mechanisms between shared values and service delivery performance}

In order to understand the relationship between shared values and service delivery performance, we compared the research model with an alternative model. We further investigated the mediating mechanisms by testing the indirect effect of shared values on service delivery performance (Table 3). With regard to mediation, we followed Zhao, Lynch and Chen's (2010, p. 204) argument that 'to establish mediation, all that matters is that the indirect effect is significant.' Hence we rely on the indirect effects results to infer about mediated relationships. 
The comparison of the study's model (base model) $\left(\chi^{2}=823.65, d f=348, \mathrm{NFI}=0.95, \mathrm{NNFI}=\right.$ $0.96, \mathrm{CFI}=0.97, \mathrm{IFI}=0.97, \mathrm{RMSEA}=0.044)$ to the alternative model with an additional direct path from shared values to service delivery performance, was anchored in the chi-square test, the model fit, and the significance of the additional path, to decide the model with the best fit. In the alternative model, the direct path from shared values to service delivery performance was found to be non-significant $(-0.03, n s)$ and the model fit remained the same $\left(\chi^{2}=823.12, d f=347, \mathrm{NFI}=0.95, \mathrm{NNFI}=0.96, \mathrm{CFI}\right.$ $=0.97, \mathrm{IFI}=0.97, \mathrm{RMSEA}=0.044)$. When conducting the chi-square difference test between the base model and the alternative model, the test was found to be non-significant at $1 \%$. Hence as the additional path was non-significant and did not improve the model fit (i.e., the base model fits the data as well as the alternative model), based on the principle of parsimony the base model was considered the model with the best fit ${ }^{1}$.

The indirect effect of shared values on service delivery performance is statistically significant $(0.07, p<0.01)$, corroborating the underlying assumption in our model that this relationship is mediated by POS, emotional exhaustion, and job attitudes, namely affective organizational commitment and job satisfaction. Accordingly, COR theory provides a theoretical basis for the mediating mechanisms that exist between shared values and service delivery performance.

\section{Discussion}

This study provides a key theoretical contribution to the human resource management literature by proposing a model that investigates the relationship between shared values and service delivery performance in the context of FLEs. By developing and testing a conceptual framework to understand how shared values may influence service delivery performance of FLEs, we expand on the existing understanding of the behavioral outcomes of shared values, namely, job performance (see Edwards \&

\footnotetext{
${ }^{1}$ We also tested a second alternative model with an additional direct path from POS to service delivery performance. The additional path from POS to service delivery performance was found to be non-significant $(0.03, n s)$, and the model fit did not improve $\left(\chi^{2}=823.54, d f=347, \mathrm{NFI}=0.95, \mathrm{NNFI}=0.96, \mathrm{CFI}=0.97, \mathrm{IFI}=0.97\right.$ and $\left.\mathrm{RMSEA}=0.044\right)$. When conducting the chi-square difference test between the base model and this alternative model, the test was found to be non-significant at $1 \%$.
} 
Cable, 2009; Maden \& Kabasakal, 2014). In particular, this study brings insights into the underlying mechanisms that intervene in this relationship. Consistent with the COR theory, our study demonstrates the significance of shared values as a critical workplace resource that could lead to a reservoir of resources. Ultimately, shared values as a key workplace resource enhances the service delivery performance of FLEs through these relevant mechanisms. The study also endorses POS, emotional exhaustion, job satisfaction, and affective organizational commitment as the key intervening mechanisms in the relationship. As shown in the alternative model analysis, the direct relationship between shared values and service delivery performance is non-significant, which further confirms that this relationship exists through the simultaneous inclusion of several intervening variables. Our findings reveal that all the intervening variables are significantly related (see $H 3$ to $H 8$ ) and thus their coexistence and established relationships are relevant in contributing toward a significant indirect effect between shared values and service delivery performance.

Generally speaking, when analyzing the relationships among the intervening variables, our findings corroborate results from previous research. In particular, POS emerges as critical for organizations, as employees who perceive greater organizational support not only tend to experience lower emotional exhaustion but also higher job satisfaction and affective organizational commitment, which ultimately enhance service delivery performance. Perceived organizational support is also seen as a relevant antecedent that reduces emotional exhaustion, showing that employees that feel supported by the organization will tend to present lower levels of depleted energy due to their work conditions (e.g., Karatepe, 2015). Similarly, when employees' perceptions are of high levels of organizational support, they will tend to respond favorably to the organization, showing an affective organizational commitment (e.g., Kurtessis et al., 2017). When employees feel that the organization values their contribution (POS), they will also feel happier in their work environment and more satisfied in their job (e.g., Riggle et al., 2009). 
Findings also confirmed the negative effects of emotional exhaustion on affective organizational commitment (e.g., Hur et al., 2013) and job satisfaction (e.g., Mahoney et al., 2011). Once again, the results highlight the harmful effect that emotional exhaustion/burnout may have on the willingness of the employee to contribute/identify with the organization, as well as their well-being on the job. Finally, when FLEs perceive that their organization values their contributions and cares about their welfare, they tend to be more satisfied with their jobs and emotionally attached to the firm (Rhoades et al., 2001). This in turn influences their service delivery performance. Our findings corroborated that the transitory nature of job satisfaction is confirmed to positively affect a consistent response of affective organizational commitment (e.g., Gunlu et al., 2010).

The study also addresses the role of workplace resources, such as shared values, in tackling employee emotional exhaustion (Demerouti \& Bakker, 2011; Hobfoll, 2011). Shared values were shown to be particularly beneficial for FLEs. Employees presenting higher shared values tend to experience less emotional exhaustion. This finding expands the existing literature focusing on the direct connection between shared values and attitudes (Verquer, Beehr, \& Wagner, 2003) by establishing a new link between shared values and emotional exhaustion. This result also emphasizes the importance of the alignment between the individual and the organization's values in reducing negative employee feelings.

Our study also sheds light on how emotional exhaustion may influence FLEs' performance. Although emotional exhaustion has been found to exert a direct impact on some aspects of FLE job performance, such as productivity (Witt et al., 2004) and service recovery performance (Choi, Kim, Lee, \& Lee, 2014; Karatepe \& Choubtarash, 2014; Kim, Paek, Choi, \& Lee, 2012), our findings reveal an indirect effect of emotional exhaustion on service delivery performance via attitudes, namely affective organizational commitment and job satisfaction, rather than a direct effect. This echoes the contentions of past literature that emotional exhaustion may not directly impact some service-related aspects of FLE job performance (see Witt et al., 2004), such as service delivery performance. This is an 
important result, which demonstrates that emotional exhaustion may impact differently, namely directly or indirectly, various aspects of FLE job performance.

\section{Practical implications}

Overall, our study raises relevant implications for HR managers to better understand the way shared values and FLEs' service delivery performance may be related. The study further derives relevant insights into key variables that affect FLEs' service delivery performance. In particular, we make suggestions for HR practices aimed at enhancing service delivery performance that can be applied when the prospective employee connects with the company, namely, HR practices in terms of selection and recruitment, and once the employee is employed by the company, through HR practices aimed at retention.

Human resource practices related to employee selection, recruitment, and retention, should take into consideration the alignment of employee's and organization's values. During selection and recruitment, managers ought to reflect in their job adverts the values the organization stands for. In particular, job adverts should contain those values that are related to professionalism, ethics, creativity, industry leadership, superior quality and service, and employee morale and satisfaction. Such practice would deter potential applicants whose values are not aligned with the company's values from applying. The interview process should include ways of measuring the congruence between applicants' values and company values. Hired FLEs should share the values of the organization.

Values should also be managed as a resource during the employment stage to facilitate employee retention. In terms of retention of current employees, value congruence expedites communication (Edwards \& Cable, 2009) and, ultimately, employees experience less anxiety and dissonance (Maden \& Kabasakal, 2014). Under such circumstances companies may use shared values to reduce the emotional exhaustion of FLEs. To instill value sharing and reduce emotional exhaustion the company can offer high-quality training programs to be attended by employees along with senior managers. 
Training should include professional behaviors, ethics, service innovation, and service quality. Senior management should also actively embrace and implement the values set in the training programs by 'walking the walk' and leading by example. Positive effects of these training programs, such as POS (see Rhoades \& Eisenberger, 2002) and reduced emotional exhaustion, would be expected to follow.

In order to enhance the impact of shared values on FLEs' service delivery performance, managers should exploit key mechanisms that directly or indirectly have an impact on delivery performance. In particular, managers should cultivate POS, affective organizational commitment, job satisfaction, and low emotional exhaustion. To this endeavor, leaders should make an effort to promote a work environment in which employees perceive the organization as valuing their contributions. For instance, favorable job conditions ought to be nurtured: recognizing employees' work with awards, promotions, bonuses, etc. (Rhoades \& Eisenberger, 2002). Additionally, the organization should show that it cares about employees' welfare, for instance, by identifying FLEs' concerns and providing help in addressing these concerns, such as implementing HR practices that support a work-life balance thus mitigating the conditions that lead to emotional exhaustion.

\section{Limitations and future research}

While the study findings provide important insights for human resource management research, it is important to recognize the limitations of the study, and to suggest potentially fruitful avenues for further research. The first limitation of the study is that the data were collected at one specific point in time using one type of respondent. Therefore while no causal inferences can be made our model, like previous studies conducted in the past utilizing similar methodology, provides 'a feasible explanation of the observed relationships' among the variables 'in the data' (Bettencourt, Brown, \& MacKenzie, 2005, p. 154). Second, this research was conducted in a single organization, which may limit the generalizability of the results to other service organizations. Future research in other companies in the same industry and in other service industries (e.g., airline, banking, hotel services) across different 
countries is therefore desirable. Finally, future research may look into the role of potential moderators, such as justice or personality traits, that may affect the relationships identified in this study. 


\section{References}

Alarcon, G. M. (2011). A meta-analysis of burnout with job demands, resources, and attitudes. Journal of Vocational Behavior, 79(2), 549-562.

Armeli, S., Eisenberger, R., Fasolo, P., \& Lynch, P. D. (1998). Perceived organizational support and police performance: The moderating influence of socio-emotional needs. Journal of Applied Psychology, 83(2), 288-297.

Babakus, E., Cravens, D. W., Johnston, M., \& Moncrief, W. C. (1999). The role of emotional exhaustion in sales force attitude and behavior relationships. Journal of the Academy of Marketing Science, 27(1), 58-70.

Babakus, E., Yavas, U., Karatepe, O. M., \& Avci, T. (2003). The effect of management commitment to service quality on employees' affective and performance outcomes. Journal of the Academy of Marketing Science, 31(3), 272-286.

Bagozzi, R. P. (1980). Performance and satisfaction in an industrial sales force: An examination of their antecedents and simultaneity. Journal of Marketing, 44(2), 65-77.

Bakker, A. B., \& Demerouti, E. (2007). The job demands-resources model: State of the art. Journal of Managerial Psychology, 22(3), 309-328.

Bakker, A. B., \& Schaufeli, W. B. (2000). Burnout contagion processes among teachers. Journal of Applied Social Psychology, 30(11), 2289-2308.

Berry, L. (1980). Services marketing is different. Business, 30(3), 24-29.

Bettencourt, L. A., \& Brown, S. W. (2003). Role stressors and customer-oriented boundary-spanning behaviours in service organizations. Journal of the Academy of Marketing Science, 31(4), 394408.

Bettencourt, L. A., Brown, S. W., \& MacKenzie, S. B. (2005). Customer-oriented boundary-spanning behaviours: Test of a social exchange model of antecedents. Journal of Retailing, 81(2), 141-157. 
Bitner, M. J., Booms, B. H., \& Tetreault, M. S. (1990). The service encounter: Diagnosing favorable and unfavorable incidents. Journal of Marketing, 54(1), 71-84.

Bollen, K. A. (1989). Structural equations with latent variables. New York, NY: Wiley.

Boshoff, C., \& Allen, J. (2000). The influence of selected antecedents on frontline staff's perceptions of service recovery performance. International Journal of Service Industry Management, 11(1), 63-90.

Brayfield, A. H., \& Rothe, H. F. (1951). An index of job satisfaction. Journal of Applied Psychology, $35(5), 307-311$.

Cable, D. M., \& DeRue, D. S. (2002). The convergent and discriminant validity of subjective fit perceptions. Journal of Applied Psychology, 87(5), 875-884.

Cable, D. M., \& Judge, T. A. (1996). Person-organization fit, job choice decisions, and organizational entry. Organizational Behavior and Human Decision Processes, 67(3), 294-311.

Chen, J.-S., Tsou, H. T., \& Huang, A. Y.-H. (2009). Service delivery innovation: Antecedents and impact on firm performance. Journal of Service Research, 12(1), 36-55.

Choi, C. H., Kim, T. T., Lee, G., \& Lee, S. K. (2014). Testing the stressor-strain-outcome model of customer-related social stressors in predicting emotional exhaustion, customer orientation and service recovery performance. International Journal of Hospitality Management, 36, 272-285.

Cronbach, L. J. (1951). Coefficient alpha and the internal structure of tests. Psychometrika, 16(3), 297334.

Cropanzano, R., John, C. H., Grandey, A. A., \& Toth, P. (1997). The relationship of organizational politics and support to work behaviors, attitudes, and stress. Journal of Organizational Behavior, $18(2), 159-180$.

Cropanzano, R., Rupp, D. E., \& Byrne, Z. S. (2003). The relationship of emotional exhaustion to work attitudes, job performance, and organizational citizenship behaviors. Journal of Applied Psychology, 88(1), 160-169. 
Deery, S., Iverson, R., and Walsh, J. (2002). Work relationships in telephone call centres: Understanding emotional exhaustion and employee withdrawal. Journal of Management Studies, 39, 471-496.

Demerouti, E., \& Bakker, A. B. (2011). The job demands-resources model: Challenges for future research. South African Journal of Industrial Psychology, 37(2), 1-9.

Donavan, D. T., Brown, T. J., \& Mowen, J. C. (2004). Internal benefits of service-worker customer orientation: Job satisfaction, commitment, and organizational citizenship behaviors. Journal of Marketing, 68(1), 128-146.

Edwards, J. R., \& Cable, D. M. (2009). The value of value congruence. Journal of Applied Psychology, 94(3), 654-677.

Eisenberger, R., Cummings, J., Armeli, S., \& Lynch, P. (1997). Perceived organizational support, discretionary treatment, and job satisfaction. Journal of Applied Psychology, 82(5), 812-820.

Eisenberger, R., Fasolo, P., \& Davis-LaMastro, V. (1990). Perceived organizational support and employee diligence, commitment, and innovation. Journal of Applied Psychology, 75(1), 51-59.

Eisenberger, R., Huntington, R., Hutchison, S., \& Sowa, D. (1986). Perceived organizational support. Journal of Applied Psychology, 71(3), 500-507.

Enz, C. A. (1986). Power and shared values in the corporate culture. Ann Arbor, MI: UMI Research Press.

Fornell, C., \& Larcker, D. F. (1981). Evaluating structural equation models with unobservable variables and measurement error. Journal of Marketing Research, 18(1), 39-50.

Furtmueller, E., Van Dick, R., \& Wilderom, C. (2011). Service behaviours of highly committed financial consultants. Journal of Service Management, 22, 317-343.

Gouldner, A. W. (1960). The norm of reciprocity: A preliminary statement. American Sociological Review, 25(2), 161-178. 
Gunlu, E., Aksarayli, M., \& Perçin, N. S. (2010). Job satisfaction and organizational commitment of hotel managers in Turkey. International Journal of Contemporary Hospitality Management, 22(5), 693-717.

Hair, J. F., Black, W. C., Anderson, R. E., Babin, B. J., \& Tatham, R. L. (2006). Multivariate data analysis (6th ed.). Upper Saddle River, NJ: Pearson Prentice Hall.

Halbesleben, J. R., \& Bowler, W. M. (2007). Emotional exhaustion and job performance: The mediating role of motivation. Journal of Applied Psychology, 92(1), 93-106.

Hartline, M. D., Maxham III, J. G., \& McKee, D. O. (2000). Corridors of influence in the dissemination of customer-orientated strategy to customer contact service employees. Journal of Marketing, 64(2), 35-50.

Hayton, J. C., Carnabuci, G., \& Eisenberger, R. (2012). With a little help from my colleagues: A social embeddedness approach to perceived organizational support. Journal of Organizational Behavior, 33(2), 235-249.

He, Y., Wenli, L., \& Lai, K. K. (2011). Service climate, employee commitment and customer satisfaction. International Journal of Contemporary Hospitality Management, 23(5), 592-607.

Hobfoll, S. E. (1988). The ecology of stress. New York, NY: Hemisphere.

Hobfoll, S. E. (1989). Conservation of resources: A new attempt at conceptualizing stress. American Psychologist, 44(3), 513-524.

Hobfoll, S. E. (2001). The influence of culture, community, and the nested-self in the stress process: Advancing conservation of resources theory. Applied Psychology: An International Review, 50(3), 337-370.

Hobfoll, S. E. (2011). Conservation of resource caravans and engaged settings. Journal of Occupational and Organizational Psychology, 84(1), 116-122. 
Hobfoll, S. E., Johnson, R. J., Ennis, N., \& Jackson, A. P. (2003). Resource loss, resource gain, and emotional outcomes among inner city women. Journal of Personality and Social Psychology, 84(3), 632-643.

Howell, A., Kirk-Brown, A., \& Cooper, B. K. (2012). Does congruence between espoused and enacted organizational values predict affective commitment in Australian organizations? International Journal of Human Resource Management, 23(4), 731-747. doi: 10.1080/09585192.2011.561251

Hur, W.-M., Moon, T. W., \& Jun, J.-K. (2013). The role of perceived organizational support on emotional labor in the airline industry. International Journal of Contemporary Hospitality Management, 25(1), 105-123.

Jöreskog, K. G., \& Sörbom, D. (2015). LISREL 9.20 for Windows [Computer software]. Skokie, IL: Scientific Software International, Inc.

Judge, T. A., \& Colquitt, J. A. (2004). Organizational justice and stress: The mediating role of workfamily conflict. Journal of Applied Psychology, 89(3), 395-404.

Karatepe, O. M. (2006). The effects of selected antecedents on the service recovery performance of frontline employees. The Service Industries Journal, 26(1), 39-57.

Karatepe, O. M. (2013). The effects of work overload and work-family conflict on job embeddedness and job performance. International Journal of Contemporary Hospitality Management, 25(4), 614-634.

Karatepe, O. M. (2015). Do personal resources mediate the effect of perceived organizational support on emotional exhaustion and job outcomes? International Journal of Contemporary Hospitality Management, 27(1), 4-26.

Karatepe, O. M., \& Choubtarash, H. (2014). The effects of perceived crowding, emotional dissonance, and emotional exhaustion on critical job outcomes: A study of ground staff in the airline industry. Journal of Air Transport Management, 40, 182-191. 
Karatepe, O. M., Yorganci, I., \& Haktanir, M. (2009). Outcomes of customer verbal aggression among hotel employees. International Journal of Contemporary Hospitality Management, 21(6), $713-$ 733.

Kim, T. T., Paek, S., Choi, C. H., \& Lee, G. (2012). Frontline service employees' customer-related social stressors, emotional exhaustion, and service recovery performance: Customer orientation as a moderator. Service Business, 6, 503-626.

Kristof, A. L. (1996). Person-organization fit: An integrative review of its conceptualizations, measurement, and implications. Personnel Psychology, 49, 1-49.

Kurtessis, J. N., Eisenberger, R., Ford, M. T., Buffardi, L. C., Stewart, K. A., \& Adis, C. S. (2017). Perceived organizational support: A meta-analytic evaluation of organizational support theory. Journal of Management, 43(6), 1854-1884.

Lages, C. R., \& Piercy, N. F. (2012). Key drivers of frontline employee generation of ideas for customer service improvement. Journal of Service Research, 15(2), 215-230.

Leiter, M. P., \& Maslach, C. (1988). The impact of interpersonal environment on burnout and organization commitment. Journal of Organizational Behavior, 9(4), 297-308.

Lindell, M. K., \& Whitney, D. J. (2001). Accounting for common method variance in cross-sectional research designs. Journal of Applied Psychology, 86(1), 114-121.

Locke, E. A. (1976). The nature and causes of job satisfaction. In M. D. Dunnette (Ed.), Handbook of industrial and organizational psychology (pp. 1297-1349). Chicago, IL: Rand-McNally.

Maden C., \& Kabasakal, H. (2014). The simultaneous effects of fit with organizations, jobs and supervisors on major employee outcomes in Turkish banks: Does organizational support matter? International Journal of Human Resource Management, 25(3), 341-366. doi: $10.1080 / 09585192.2013 .789446$

Mahoney, K., Buboltz, W. Jr., Buckner, J., \& Doverspike, D. (2011). Emotional labor in American professors. Journal of Occupational Health Psychology, 16(4), 406-423. 
Malhotra, N., \& Ackfeldt, A. L. (2016). Internal communication and prosocial service behaviors of front-line employees: Investigating mediating mechanisms. Journal of Business Research, 69(10), $4132-4139$.

Martinussen, M., Richardsen, A. M., \& Burke, R. J. (2007). Job demands, job resources, and burnout among police officers. Journal of Criminal Justice, 35, 239-249.

Maslach, C., \& Jackson, S. E. (1986). Maslach burnout inventory manual. Palo Alto, CA: Consulting Psychologists Press.

Maxham III, J. G., \& Netemeyer, R. G. (2003). Firms reap what they sow: The effects of shared values and perceived organizational justice on customers' evaluation of complaint handling. Journal of Marketing, 67(1), 29-45.

Meglino, B. M., \& Ravlin, E. C. (1998). Individual values in organizations: Concepts, controversies, and research. Journal of Management, 24(3), 351-389.

Meyer, J. P., Stanley, D. J., Herscovitch, L., \& Topolnytsky, L. (2002). Affective, continuance, and normative commitment to the organization: A meta-analysis of antecedents, correlates, and consequences. Journal of Vocational Behavior, 61(1), 20-52.

Mitchell, T. R., Holtom, B. C., Lee, T. W., Sablynski, C. J., \& Erez, M. (2001). Why people stay: Using job embeddedness to predict voluntary turnover. Academy of Management Journal, 44(6), 11021121.

Morgan, R., \& Hunt, S. (1994). The commitment-trust theory of relationship marketing. Journal of Marketing, 58(3), 20-38.

Mowday, R. T., Steers, R. M., \& Porter, L. W. (1979). The measurement of organizational commitment. Journal of Vocational Behavior, 14(2), 224-247.

Mulki, J. P., Jaramillo, J. F., \& Locander, W. B. (2007). Effect of ethical climate on turnover intention: Linking attitudinal and stress theory. Journal of Business Ethics, 78(4), 559-574. 
Panaccio, A., \& Vandenberghe, C. (2009). Perceived organizational support, organizational commitment and psychological well-being: A longitudinal study. Journal of Vocational Behavior, 75(2), 224-236.

Podsakoff, P. M., MacKenzie, S. B., \& Podsakoff, N. P. (2012). Sources of method bias in social science research and recommendations on how to control it. Annual Review of Psychology, 63, 539-569.

Podsakoff, P. M., MacKenzie, S. B., Podsakoff, N. P., \& Lee, J.-Y. (2003). Common method biases in behavioral research: A critical review of the literature and recommended remedies. Journal of Applied Psychology, 88(5), 879-903.

Podsakoff, P. M., \& Organ, D. W. (1986). Self-reports in organizational research: Problems and prospects. Journal of Management, 12(4), 531-544.

Porter, L. W., Steers, R. M., Mowday, R. T., \& Boulian, P. V. (1974). Organizational commitment, job satisfaction, and turnover among psychiatric technicians. Journal of Applied Psychology, 59(5), 603-609.

Presbitero, A., Roxas, B., \& Chadee, D. (2016). Looking beyond HRM practices in enhancing employee retention in BPOs: Focus on employee-organisation value fit. International Journal of Human Resource Management, 27(6), 635-652.

Rhoades, L., \& Eisenberger, R. (2002). Perceived organizational support: A review of the literature. Journal of Applied Psychology, 87(4), 698-714.

Rhoades, L., Eisenberger, R., \& Armeli, S. (2001). Affective commitment to the organization: The contribution of perceived organizational support. Journal of Applied Psychology, 86(5), 825-836.

Riggle, R. J., Edmondson, D. R., \& Hansen, J. D. (2009). A meta-analysis of the relationship between perceived organizational support and job outcomes: 20 years of research. Journal of Business Research, 62(10), 1027-1030. 
Schaufeli, W. B., and Bakker, A. B. (2004). Job demands, job resources, and their relationship with burnout and engagement: A multi-sample study. Journal of Organizational Behavior, 25, 293437.

Schneider, B., Goldstein, H. W., \& Smith, D. B. (1995). The ASA framework: An update. Personnel Psychology, 48(4), 747-773.

Singh, J., Goolsby, J. R., \& Rhoads, G. K. (1994). Behavioral and psychological consequences of boundary-spanning burnout for customer service representatives. Journal of Marketing Research, 31(4), 558-569.

Thanacoody, P. R., Newman, A., \& Fuchs, S. (2014). Affective commitment and turnover intentions among healthcare professionals: The role of emotional exhaustion and disengagement. International Journal of Human Resource Management, 25(13), 1841-1857.

Tourigny, L., Baba, V. V., Han, J., \& Wang, X. (2013). Emotional exhaustion and job performance: The mediating role of organizational commitment. International Journal of Human Resource Management, 24(3), 514-532.

Vandenberghe, C., Bentein, K., Michon, R., Chebat, J.-C., Tremblay, M., \& Fils, J.-F. (2007). An examination of the role of perceived support and employee commitment in employee-customer encounters. Journal of Applied Psychology, 92, 1177-1187.

Verquer, M. L., Beehr, T. A., and Wagner, S. H. (2003). A meta-analysis of relations between personorganization fit and work attitudes. Journal of Vocational Behavior, 63, 473-489.

Wasmer, D. J., \& Bruner, G. C. (1991). Using organizational culture to design internal marketing strategies. Journal of Services Marketing, 5(Winter), 35-46.

Watrous, K. M., Huffman, A. H., \& Pritchard, R. D. (2006). When co-workers and managers quit: The effects of turnover and shared values on performance. Journal of Business and Psychology, 21(4), $103-126$. 
Wheeler, A. R., Harris, K. J., \& Sablynski, C. J. (2012). How do employees invest abundant resources? The mediating role of work effort in the job-embeddedness/job-performance relationship. Journal of Applied Social Psychology, 42(S1, December), 244-266.

Williams, L. J., Hartman, N., \& Cavazotte, F. (2010). Method variance and marker variables: A review and comprehensive CFA marker technique. Organizational Research Methods, 13(3), $477-514$.

Witt, L. A., Andrews, M. C., \& Carlson, D. S. (2004). When conscientiousness isn't enough: Emotional exhaustion and performance among call center customer service representatives. Journal of Management, 30(1), 149-160.

Wright, T. A., \& Cropanzano, R. (1998). Emotional exhaustion as a predictor of job performance and voluntary turnover. Journal of Applied Psychology, 83(3), 486-493.

Wright, T. A., \& Hobfoll, S. E. (2004). Commitment, psychological well-being and job performance: An examination of conservation of resources (COR) theory and job burnout. Journal of Business and Management, 9(4), 389-406.

Yoon, M. H., Beatty, S. E., \& Suh, J. (2001). The effect of work climate on critical employee and customer outcomes: An employee-level analysis. International Journal of Service Industry Management, 12(5), 500-521.

Young, S. A., \& Parker, C. P. (1999). Predicting collective climates: Assessing the role of shared work values, needs, employee interaction and work group membership. Journal of Organizational Behavior, 20(7), 1199-1218.

Zhao, X., Lynch, J. G., \& Chen Q. (2010). Reconsidering Baron and Kenny: Myths and truths about mediation tests. Journal of Consumer Research, 37(August), 197-206. 


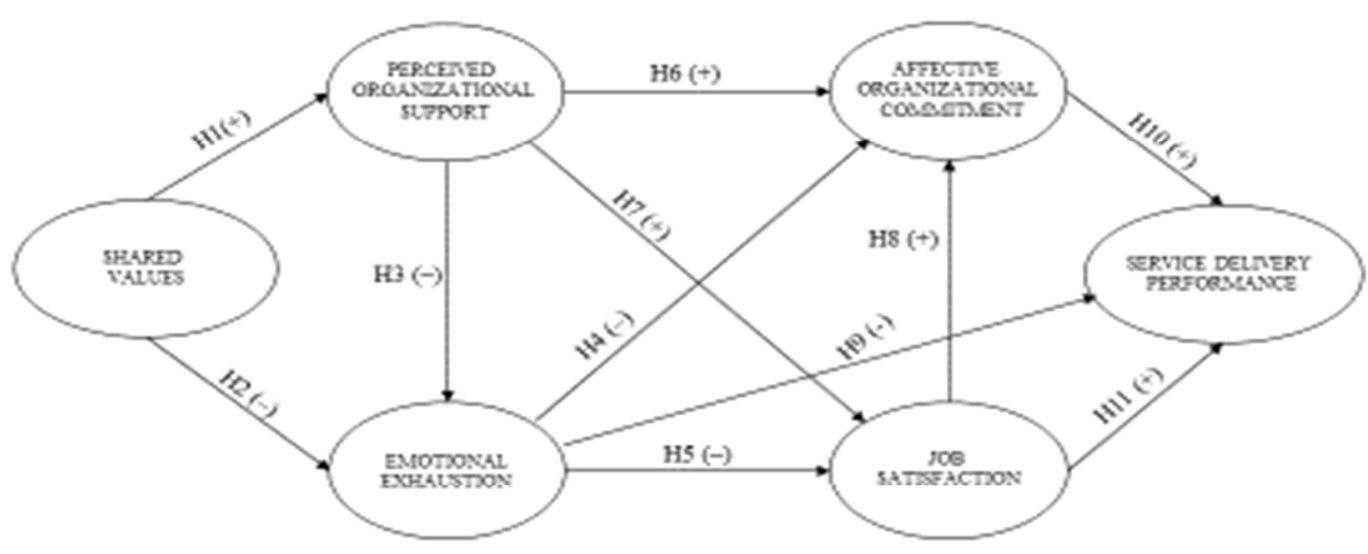




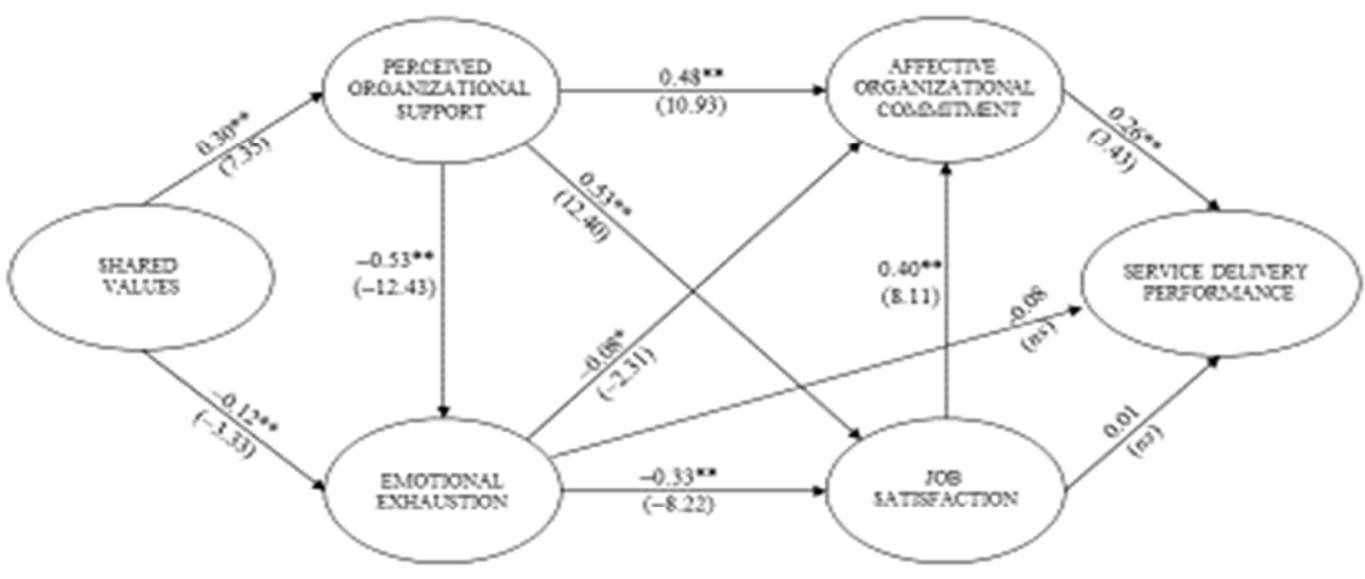

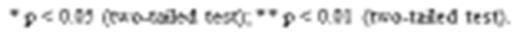


Table 1. Matrix of correlations among latent constructs.

\begin{tabular}{lcccccccc}
\hline Construct & Mean $^{2}$ & SD & 1 & 2 & 3 & 4 & 5 & 6 \\
\hline 1. POS & 4.45 & 1.54 & $0.70 / .88$ & & & & & \\
2. SV & 4.53 & 1.60 & $0.30^{*}$ & $0.73 / 0.94$ & & & & \\
3. EE & 2.77 & 1.01 & $-0.56^{*}$ & $-0.27^{*}$ & $0.61 / 0.90$ & & & \\
4. AOC & 4.16 & 1.62 & $0.82^{*}$ & $0.28^{*}$ & $-0.59^{*}$ & $0.77 / 0.95$ & & \\
5. JS & 3.34 & 1.01 & $0.73^{*}$ & $0.22^{*}$ & $-0.60^{*}$ & $0.80^{*}$ & $0.68 / 0.87$ & \\
6. SDP & 5.54 & 1.19 & $0.28^{*}$ & 0.08 & $-0.23^{*}$ & $0.33^{*}$ & $0.30^{*}$ & $0.72 / 0.88$ \\
\hline
\end{tabular}

Note: $*$ Correlation significant at $p<0.01$ (two-tailed).

Average variance extracted (Fornell \& Larcker, 1981) and Cronbach's alpha values (Cronbach, 1951) for each construct are on the diagonal.

$\mathrm{SV}=$ Shared values

POS = Perceived organizational support

$\mathrm{EE}=$ Emotional exhaustion
$\mathrm{JS}=$ Job satisfaction

AOC = Affective organizational commitment

SDP $=$ Service delivery performance

2 POS, SV, AOC, and SDP were measured on a 7-point scale. EE and JS were measured on a 5-point scale. 
Table 2. Measurement model.

\begin{tabular}{ll}
\hline Factors & $\begin{array}{l}\text { Standardized } \\
\text { loadings }^{a}\end{array}$ \\
\hline
\end{tabular}

Shared values $(\rho=0.94)$

[Company name] has the same values as I do with regard to...

Professionalism: behaving in a business-like manner. ${ }^{b}$

Ethics: a company's concern for the honesty and integrity of all employees in conducting company activities.

Creativity: being imaginative and innovative in the development and delivery of services.

Industry leadership: being considered by everyone in the industry to be the number one company.

Superior quality and service: providing high-quality services to customers as quickly and friendly as possible.

Employee morale and satisfaction: a positive feeling for the company and job, a sense of belonging.

\section{Perceived organizational support $(\rho=0.88)$}

[Company name] really cares about my well-being. ${ }^{b} 0.83$

[Company name] cares about my general satisfaction at work.

[Company name] takes pride in my accomplishments at work.

Emotional exhaustion $(\rho=0.90)$

I feel emotionally drained by my work. ${ }^{b}$

I feel tired when I get up in the morning and have to face another day on the job.

$0.69(19.39)$

I worry that this job is hardening me emotionally.

$0.76(21.92)$

I feel like I am at the end of my tether.

Affective organizational commitment $(\rho=0.94)$

I talk up [company name] to my friends as a great organization to work for. ${ }^{b}$

I am proud to tell others that I am a part of [company name].

[Company name] inspires the very best in me in the way of job performance.

I am extremely glad I chose [company name] to work for over other companies I was considering at the time.

For me, [company name] is the best of all possible organizations to work for.

Job satisfaction $(\rho=0.87)$

Most days I am enthusiastic about my work. ${ }^{b}$

I feel fairly satisfied with my present job.

$0.83(25.08)$ 
Service delivery performance $(\rho=0.88)$

I follow up in a timely manner to customer requests and problems. ${ }^{b} \quad 0.77$

Regardless of circumstances, I am exceptionally courteous and

respectful to customers.

$0.86(23.82)$

I follow through in a conscientious manner on promises to customers.

$0.90(24.40)$

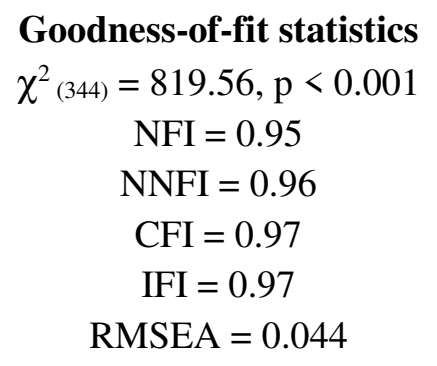

Notes: ${ }^{a} \mathrm{z}$-values are in parentheses.

${ }^{b}$ Item fixed to set the scale.

$\rho=$ Composite reliability (Bagozzi, 1980). 
Table 3. Structural model: standardized parameter estimates and fit indices.

\begin{tabular}{|c|c|c|c|c|c|c|c|}
\hline & & \multicolumn{2}{|l|}{ Direct effects } & \multicolumn{2}{|c|}{ Indirect effects } & \multicolumn{2}{|c|}{ Total effects } \\
\hline & & $\begin{array}{l}\text { Standardized } \\
\text { coefficient }\end{array}$ & $z$-value & $\begin{array}{l}\text { Standardized } \\
\text { coefficient }\end{array}$ & $z$-value & $\begin{array}{l}\text { Standardized } \\
\text { coefficient }\end{array}$ & $z$-value \\
\hline \multicolumn{8}{|l|}{$\begin{array}{l}\text { Estimated } \\
\text { path }\end{array}$} \\
\hline $\mathrm{SV} \rightarrow \mathrm{POS}$ & $\mathrm{H} 1$ & $0.30^{* * *}$ & 7.35 & & & & \\
\hline $\mathrm{SV} \rightarrow \mathrm{EE}$ & $\mathrm{H} 2$ & $-0.12 * * *$ & -3.33 & & & & \\
\hline $\mathrm{POS} \rightarrow \mathrm{EE}$ & $\mathrm{H} 3$ & $-0.53 * * *$ & -12.43 & & & & \\
\hline $\mathrm{EE} \rightarrow \mathrm{AOC}$ & $\mathrm{H} 4$ & $-0.08 * *$ & -2.31 & & & & \\
\hline $\mathrm{EE} \rightarrow \mathrm{JS}$ & H5 & $-0.33 * * *$ & -8.22 & & & & \\
\hline $\mathrm{POS} \rightarrow \mathrm{AOC}$ & H6 & $0.48 * * *$ & 10.93 & & & & \\
\hline $\mathrm{POS} \rightarrow \mathrm{JS}$ & $\mathrm{H} 7$ & $0.53 * * *$ & 12.40 & & & & \\
\hline $\mathrm{JS} \rightarrow \mathrm{AOC}$ & $\mathrm{H} 8$ & $0.40^{* * *}$ & 8.11 & & & & \\
\hline $\mathrm{EE} \rightarrow \mathrm{SDP}$ & H9 & -0.08 & -1.38 & $-0.06^{* * *}$ & -2.70 & $-0.15 * * *$ & -2.92 \\
\hline $\mathrm{AOC} \rightarrow \mathrm{SDP}$ & $\mathrm{H} 10$ & $0.26^{* * *}$ & 3.43 & & & & \\
\hline $\mathrm{JS} \rightarrow \mathrm{SDP}$ & H11 & 0.01 & 0.14 & $0.12^{* * *}$ & 3.17 & $0.14^{*}$ & 1.72 \\
\hline $\mathrm{SV} \rightarrow \mathrm{SDP}$ & & & & $0.07 * * *$ & 5.70 & $0.07 * * *$ & 5.70 \\
\hline \multicolumn{8}{|l|}{$\begin{array}{l}\text { Control }^{\mathrm{i}} \\
\text { variables }\end{array}$} \\
\hline Age $\rightarrow$ POS & & $0.13^{* * *}$ & 2.99 & & & & \\
\hline $\mathrm{Age} \rightarrow \mathrm{EE}$ & & $0.11 * * *$ & 2.69 & & & & \\
\hline Age $\rightarrow$ JS & & $0.20^{* * *}$ & 5.80 & & & & \\
\hline Gender $\rightarrow$ JS & & $-0.07 * *$ & -2.37 & & & & \\
\hline Tenure $\rightarrow$ POS & & $-0.12 * * *$ & -2.85 & & & & \\
\hline Tenure $\rightarrow$ EE & & $0.07^{*}$ & 1.85 & & & & \\
\hline
\end{tabular}




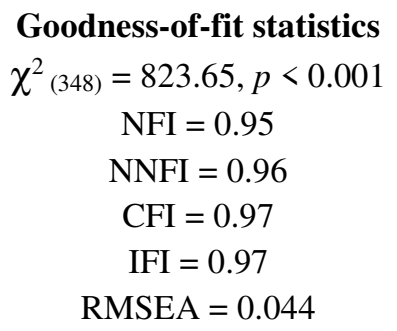

Note:

$* p<0.10$ (two-tailed test); ** $p<0.05$ (two-tailed test); *** $p<0.01$ (two-tailed test).

$\mathrm{SV}=$ Shared values

POS $=$ Perceived organizational support

$\mathrm{EE}=$ Emotional exhaustion
$\mathrm{JS}=$ Job satisfaction

AOC = Affective organizational commitment

$\mathrm{SDP}=$ Service delivery performance

${ }^{\text {i }}$ All the other relationships between the control variables and POS, EE, AOC, and SDP are non-significant. 